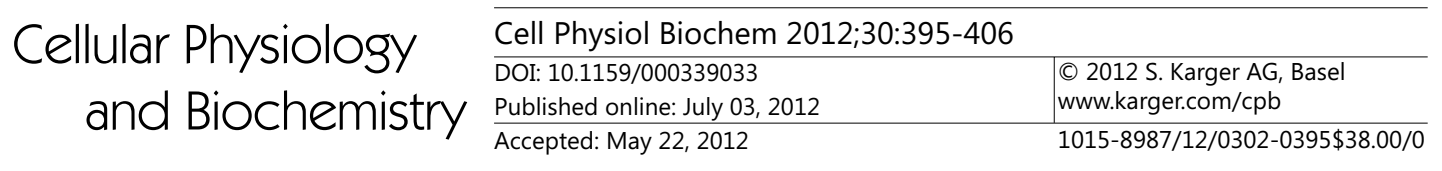

\title{
Shear-induced Volume Decrease in MDCK Cells
}

\author{
Jinseok Heo ${ }^{1,2 *}$ Frederick Sachs ${ }^{1} \quad$ Jianbin Wang ${ }^{2} \quad$ Susan Z. Hua ${ }^{1,2}$ \\ 'Department of Physiology and Biophysics, and ${ }^{2}$ Department of Mechanical and Aerospace \\ Engineering, SUNY-Buffalo, Buffalo, NY, ${ }^{*}$ Current address: Department of Chemistry, Buffalo State \\ College, Buffalo, NY 14222
}

\section{Key Words}

Cell volume • Flow shear stress $•$ MDCK $・$ Impedance-based sensor

\begin{abstract}
Using a microfluidic cell volume sensor we measured the change in the cell volume of MadinDarby Canine Kidney (MDCK) cells induced by shear stress. An increase in shear stress from 0.2 to $2.0 \mathrm{dyn} / \mathrm{cm}^{2}$ resulted in a volume decrease to a steady state volume $\sim 20-30 \%$ smaller than the initial resting cell volume. Independent experiments based on fluorescence quenching confirmed the volume reduction. This shear-induced cell shrinkage was irreversible on the time scale of the experiment ( $30 \mathrm{~min})$. Treatment of $0.1 \mu \mathrm{M} \mathrm{Hg}{ }^{2+}$ significantly inhibited the volume decrease, suggesting that the shear-induced cell shrinkage is associated with water efflux through aquaporins. The volume decrease cannot be inhibited by $75 \mathrm{mM}$ TEA, $100 \mu \mathrm{M}$ DIDS, or $100 \mu \mathrm{M} \mathrm{Gd}^{3+}$ suggesting that volume reduction is not directly mediated by $\mathrm{K}^{+}$and $\mathrm{Cl}^{-}$channels that typically function during regulatory volume decrease (RVD), nor is it through cationic stretch-activated ion channels (SACs). The process also appears to be $\mathrm{Ca}^{2+}$ independent because it was insensitive to intracellular $\mathrm{Ca}^{2+}$ level. Since cell volume is determined by the intracellular water content, we postulate that the shear induced reductions in cell volume may arise from increased intracellular hydrostatic pressure as the cell is deformed under flow, which promotes the efflux of water. The increase in internal pressure in a deformable object under the flow is supported by the finite element mechanical model.
\end{abstract}

Copyright (C 2012 S. Karger AG, Basel

\section{Introduction}

Renal epithelial cells are exposed to a broad range of shear stresses due to the change in urinary flow under physiological and pathological conditions. Flow shear stress can affect the physiological behavior of renal tubule cells by altering ion channel activity $[1,2]$, 


\begin{tabular}{|c|c|c|}
\hline $\mathrm{Col}$ & Cell Physiol Biochem 2012;30:395-406 & \\
\hline and Biochemistry & $\begin{array}{l}\text { DOI: 10.1159/000339033 } \\
\text { Published online: July 03, } 2012\end{array}$ & $\begin{array}{l}\text { (c) } 2012 \text { S. Karger AG, Basel } \\
\text { www.karger.com/cpb }\end{array}$ \\
\hline
\end{tabular}

organization of cytoskeleton [3-5], gene expression [6], or transcription factors [4]. Thus, sensing and responding to shear stress is an important function of epithelial cells.

Flow induced changes in ion transport have been observed with patch-clamp recording $[1,7]$. Increases in shear stress cause $\mathrm{Ca}^{2+}$ influx in many cell types [8-11] and that activates a cascade of signal pathways affecting biochemical reactions and ion transport [12]. Flow-dependent $\mathrm{Ca}^{2+}$-activated $\mathrm{K}^{+}$channels are postulated to account for the increase of $\mathrm{K}^{+}$secretion under flow in the rabbit connecting tubule (CNT) [1] and cortical collecting ducts (CCD) [13, 14]. Shear stress might also activate stretch-activated ion channels (SACs) by creating gradients in membrane tension [15]. It has been recently reported that SACs are responsive to both shear stress and osmotic swelling $[16,17]$. Since the influx or efflux of osmolytes from cells is accompanied by the water transport, effect of shear stress on membrane transport will cause the changes in cell volume. In addition, cell volume could also be changed by shear stress induced change in cell shape that promotes the efflux of water. Simple mechanics predicts that shear stress can introduce an increase in intracellular pressure due to cell deformation and that pressure will increase the efflux of water. These may result in changes in solute concentration and also in cytoplasmic stress with its biochemical consequences $[18,19]$.

Using the cell volume sensor based on an impedance measurement [20], we observed that cell volume decreases in response to increased flow shear stress. The change in the cell volume was only partly reversible within the experimental duration of $\sim 1 \mathrm{hr}$, suggesting that the cell structure had been altered during shear stress application. The shear-induced volume reduction was inhibited by $\mathrm{Hg}^{2+}$ suggesting the involvement of water efflux. Pharmacological blocking tests revealed that the volume changes did not utilize $\mathrm{Ca}^{2+}$-activated signaling pathways, $\mathrm{K}^{+}$or $\mathrm{Cl}^{-}$channels, $\mathrm{Na}^{+}-\mathrm{H}$ exchange or SACs. Finite element analysis results suggest that the decrease in cell volume by shear stress could be attributed to the compressive stress inside the cells that changes the cell shape and enhances water efflux.

\section{Materials and Methods}

\section{Solution preparation}

Hypotonic solution (168 mOsm) consisted of $75 \mathrm{mM} \mathrm{NaCl}, 5 \mathrm{mM} \mathrm{KCl}, 2 \mathrm{mM} \mathrm{MgCl}, 1 \mathrm{mM} \mathrm{CaCl}{ }_{2}$ with $10 \mathrm{mM}$ HEPES at $\mathrm{pH}$ 7.4. Isotonic (320 mOsm) solution was prepared by adding mannitol to the hypotonic solution. This isotonic solution was lightly titrated with $\mathrm{NaCl}$ to have the same conductivity as the hypotonic solution. This titration step added less than $0.1 \mathrm{mM} \mathrm{NaCl}$ to the isotonic solution. The osmolarity was measured using an osmometer (Advanced Model 303, Advanced Instrument, Norwood, MA). Drug solutions of $10 \mathrm{mM}$ of 4,4'-diisothiocyanatostilbene-2,2'-disulfonic acid (DIDS) and $100 \mathrm{mM}$ amiloride solutions were prepared in DMSO and stored in the freezer. A $10 \mu \mathrm{M}$ stock of $\mathrm{HgCl}_{2}$ solution was prepared in isotonic solution and further diluted to $0.1 \mu \mathrm{M}$ for experiments. Gadolinium chloride was prepared as a $10 \mathrm{mM}$ stock solution in water. The solution of 5-(N,N-dimethyl)amiloride hydrochloride was prepared in isotonic saline and 75 $\mathrm{mM}$ tetraethylammonium (TEA) chloride solution was prepared in isotonic solution by replacing $\mathrm{NaCl}$.

\section{Cell culture}

Microscope slides were cut to $\sim 22 \mathrm{~mm} \times 13 \mathrm{~mm}$ to fit on the sensor chip and cleaned as previously described [21]. MDCK cells (ATCC) were grown to confluence on the slide in a $35 \mathrm{~mm}$ Petri dish using Dulbecco's Modified Eagle's Medium (DMEM) containing 10\% fetal bovine serum and 1\% penicillinstreptomycin. It took 4-6 days to grow the cells to confluence. The cell passage number was between 5 and 35. Cells showed good adhesion on the glass surface without specialized coatings.

Measurement of cell volume change using cell volume sensor

The cell volume sensor was described in our previous paper [20]. It measures the real part of the (extracellular) impedance of a thin flow chamber of fixed volume containing the cells. An increase in cell volume appears as an increase in extracellular resistance. A slide with attached cells was inverted over the sensor so that cells faced the chamber. The sensing chamber was $1.5 \mathrm{~mm}$ wide, $2.5 \mathrm{~mm}$ long, and 18 or $24 \mu \mathrm{m}$ thick and contained an evaporated four-electrode Pt array deposited on the surface by e-beam deposition. 


\begin{tabular}{|c|c|c|}
\hline Coll & Cell Physiol Biochem 2012;30:395-406 & \\
\hline and Rinchemictry & $\begin{array}{l}\text { DOI: } 10.1159 / 000339033 \\
\text { Published online: July 03, } 2012\end{array}$ & $\begin{array}{l}\text { (c) } 2012 \text { S. Karger AG, Basel } \\
\text { www.karger.com/cpb }\end{array}$ \\
\hline
\end{tabular}

The chamber resistance was measured by supplying a constant current $(100 \mathrm{~Hz}, 200 \mathrm{nA})$ to the outer pair of electrodes, while measuring the voltage between the inner pair with phase-lock detection [20]. Since the impedance of the cell membrane is high at these frequencies, the change of resistance represents the change of cell volume $[20,22]$. The solution flow rate was controlled using a syringe pump (PHD 22/2200, Harvard Apparatus, Holliston, MA). The data was plotted as the ratio of cell volume change to the resting cell volume as previously described $[20,21,23]$. To measure the resistance of the empty chamber, after an experiment was finished the chamber was perfused with a detergent (1\% Triton X-100) to permeabilize the cells and the chamber was then rinsed with isotonic solution. The resistance (or voltage) in the sensing chamber was then defined as $V_{\text {empty }}$. The ratio of the cell volume change to the resting volume at time $t$ can be approximated as:

$$
\frac{\Delta C V}{C V_{0}}=\frac{V_{t}-V_{0}}{V_{0}-V_{\text {empry }}}
$$

where, $\Delta \mathrm{CV}$ is cell volume change, $\mathrm{C} V_{o}$ is resting cell volume, $V_{t}$ is the voltage measured in the chamber at time $t$, and $V_{o}$ is the initial voltage (chamber resistance with resting cells) in isotonic solution.

As a control, cells were fixed with $4 \%$ paraformaldehyde for $10 \mathrm{~min}$ and treated with $0.1 \%$ Triton $\mathrm{X}$-100 solution for $5 \mathrm{~min}$ to remove the membranes. After the fixed cells were rinsed with isotonic solution, we examined whether there was any artifactual signal that could be interpreted as a change of cell volume with shear stress and found no significant change. We display raw data for this measurement because the fixed cells could not be removed from the sensing chamber to measure $V_{\text {empty }}$. To observe a change in the cell morphology, we recorded micrographs of the cells while collecting cell volume data using an upright microscope (Zeiss) equipped with a 10x objective and CCD camera.

Measurement of volume change using fluorescence concentration quenching [24]

To check out our method against published methods we also measured volume changes using fluorescence quenching. This method measures concentration-dependent quenching of intracellular calcein [24]. MDCK cells were grown to confluence and after rinsing with isotonic solution, they were incubated with isotonic solution containing $4 \mu \mathrm{M}$ of calcein-AM (Invitrogen, Carlsbad, CA). To calibrate the sensitivity of the dye to cell volume changes, we exposed the cells to hypotonic and hypertonic solutions and monitored the fluorescence intensity. After we confirm that changes of cell volume caused the change of the fluorescence intensity, we examined the change in the cell volume under shear stress by using fluorescence. The relative fluorescence intensity was calculated using the following equation (Eqn. 2).

$$
I_{r e l}=\frac{\left(I_{t}-I_{B k}\right)-\left(I_{o}-I_{B k}\right)}{\left(I_{o}-I_{B k}\right)}
$$

where $I_{\text {rel }}$ is relative fluorescence intensity change, $I_{\mathrm{t}}$ is fluorescence intensity at time $t, I_{\mathrm{Bk}}$ is background fluorescence intensity, and $I_{\mathrm{o}}$ is fluorescence intensity at $t=0$.

\section{Intracellular $\mathrm{Ca}^{2+}$ measurement}

Cells were loaded with $6 \mu$ M Fluo-4 AM (Invitrogen, Carlsbad, CA) in isotonic solution for $30 \mathrm{~min}$ in an incubator. The cells were then rinsed with isotonic solution and incubated for another $10 \mathrm{~min}$. The slide was mounted on the sensor and we collected fluorescence micrographs. Time-lapse experiments were recorded using AxioVision software (Zeiss).

\section{Finite element analysis}

We built a simple 2D model and calculated the intracellular stress distribution under flow using finite element analysis (ANSYS/CFX, ANSYS Inc.). The model consists of a flow chamber having the same dimensions as the sensor and a deformable elastic cell attached to the bottom of the chamber. The model had steady flow with non-slip boundary conditions and we used two-way coupling of fluid-structure interaction method. The fluid domain was calculated by ANSYS/CFX, and the deformable cell domain was analyzed by ANSYS. The flow domain and cell domain were coupled through continuity boundary condition for displacement, traction, and velocity at the fluid-cell interface.

\section{Shear stress calculation}

We used two microfluidic sensors with different channel heights of 18 and $24 \mu \mathrm{m}$. Unless otherwise noted, the experiments were conducted using a device with $24 \mu \mathrm{m}$ channel height. Assuming confluent cells 


\section{Cellular Physiology Cell Physiol Biochem 2012;30:395-406 \\ \begin{tabular}{ll|l} 
and Biochemistry & $\begin{array}{l}\text { DOI: 10.1159/000339033 } \\
\text { Published online: July 03, 2012 }\end{array}$ & $\begin{array}{l}\text { O 2012 S. Karger AG, Basel } \\
\text { www.karger.com/cpb }\end{array}$ \\
\end{tabular}}
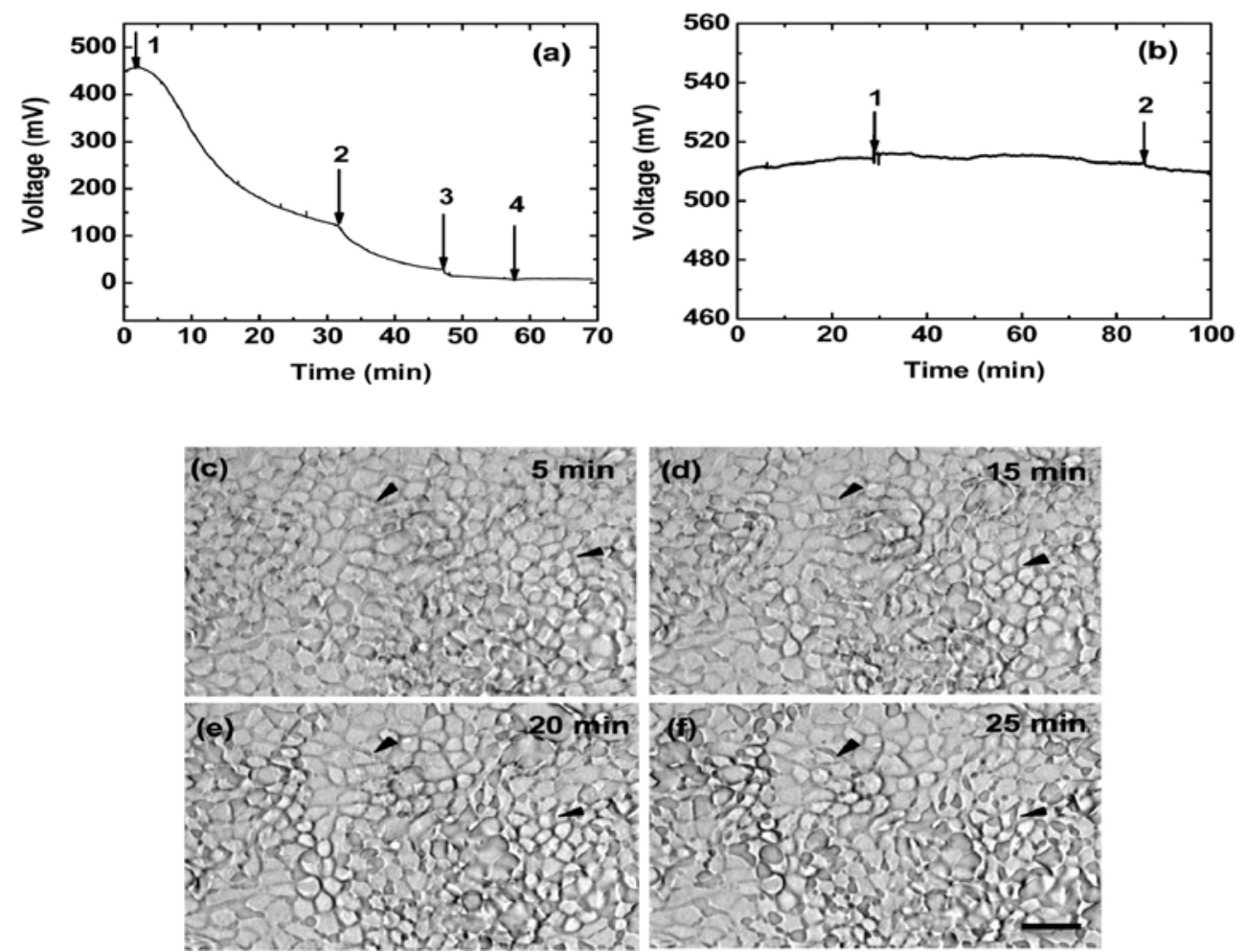

Fig. 1. (a) Resistance measurement of the sensor showing a change in the MDCK volume in response to shear flow. The arrows indicate an increase of flow rate from $0.1 \mu \mathrm{l} / \mathrm{min}\left(0.2 \mathrm{dyn} / \mathrm{cm}^{2}\right)$ to $1: 1.0 \mu \mathrm{l} / \mathrm{min}$ $\left(2.0 \mathrm{dyn} / \mathrm{cm}^{2}\right) ; 2: 5.0 \mu \mathrm{l} / \mathrm{min}\left(10 \mathrm{dyn} / \mathrm{cm}^{2}\right) ; 3: 7.5 \mu \mathrm{l} / \mathrm{min}\left(15 \mathrm{dyn} / \mathrm{cm}^{2}\right) ; 4: 10.0 \mu \mathrm{l} / \mathrm{min}\left(20 \mathrm{dyn} / \mathrm{cm}^{2}\right)$. The overall decrease of cell volume ranged from 10 to $30 \%$ from steady state. (b) Fixed cells do not respond to shear stress. The arrows in (b) indicate change of shear stress from 0.2 to 2.0 and return to $0.2 \mathrm{dyn} / \mathrm{cm}^{2}$, respectively. (c)-(f) Corresponding optical micrographs of cells obtained during the volume measurement in (a) at 5, 15, 20, and 25 min, respectively. There was no noticeable loss of cells from the chamber, but large changes in the cell morphology and widened intracellular gaps (two examples are indicated by black arrows). The scale bar is $10 \mu \mathrm{m}$.

form a planar sheet, the wall shear stress $\tau$ was calculated using [25]:

$$
\tau=\frac{6 \mu Q}{w d^{2}}
$$

here $\mu$ is viscosity, $Q$ is volume flow rate, $w$ is channel width, and $d$ is channel height, respectively. Viscosity was assumed to be $1.0 \times 10^{-3} \mathrm{~Pa}$.

\section{Results}

Shear stress induced decrease in cell volume

We initially measured the change of MDCK cell volume with stepwise increases in the flow rate using a sensor with an $18 \mu \mathrm{m}$ high channel. The cells were first exposed to low shear at $0.1 \mu \mathrm{l} / \mathrm{min}\left(0.2 \mathrm{dyn} / \mathrm{cm}^{2}\right)$ until the signal stabilized. We did not observe any noticeable $\mathrm{Ca}^{2+}$ response at this flow rate using the same chamber. We then increased the flow rate to 1,5 , 7.5 , and $10 \mu \mathrm{l} / \mathrm{min}$ corresponding to shear stress of $2.0,10,15$, and $20 \mathrm{dyn} / \mathrm{cm}^{2}$, and followed the changes of cell volume (Fig. 1a). Fig. 1a shows that a stepwise increase in the flow rate ( 0.1 to $1 \mu \mathrm{l} / \mathrm{min}$ ) caused the cells to rapidly shrink indicating a loss of intracellular water. A successive increase from $1 \mu \mathrm{l} / \mathrm{min}\left(2.0 \mathrm{dyn} / \mathrm{cm}^{2}\right)$ to $10 \mu \mathrm{l} / \mathrm{min}\left(20 \mathrm{dyn} / \mathrm{cm}^{2}\right)$ resulted in further decreases, eventually reaching a steady state volume approximately $30 \%$ smaller than the original volume. 


\begin{tabular}{rl|l} 
Cellular Physiology & Cell Physiol Biochem 2012;30:395-406 & \\
\cline { 2 - 3 } and Biochemistry & Do.1159/000339033 & $\begin{array}{l}\text { O 2012 S. Karger AG, Basel } \\
\text { www.karger.com/cpb }\end{array}$ \\
\cline { 2 - 3 } & Published online: July 03, 2012 & Heo/Sachs/Wang/Hua: Shear-induced Volume Decrease
\end{tabular}

Fig. 2. Volume change measured with fluorescence quenching. (a) The change of cell volume in response to hypotonic and hypertonic perfusion. (b) The change of cell volume in response to shear stress. Both data sets were obtained from fluorescence micrographs of MDCK cells loaded with $4 \mu \mathrm{M}$ calcein. The arrows in (a) indicates the solution change from isotonic (320 mOsm) to hypotonic (168 $\mathrm{mOm}$ ) or hypertonic solution (429 mOsm). The arrow in (b) indicates the change of the shear stress from 0.7 to $7.0 \mathrm{dyn} / \mathrm{cm}^{2}$. The plot in (b) is the average of relative intensity changes obtained from ten different locations in each of the micrographs. The error bar indicates the standard deviation.
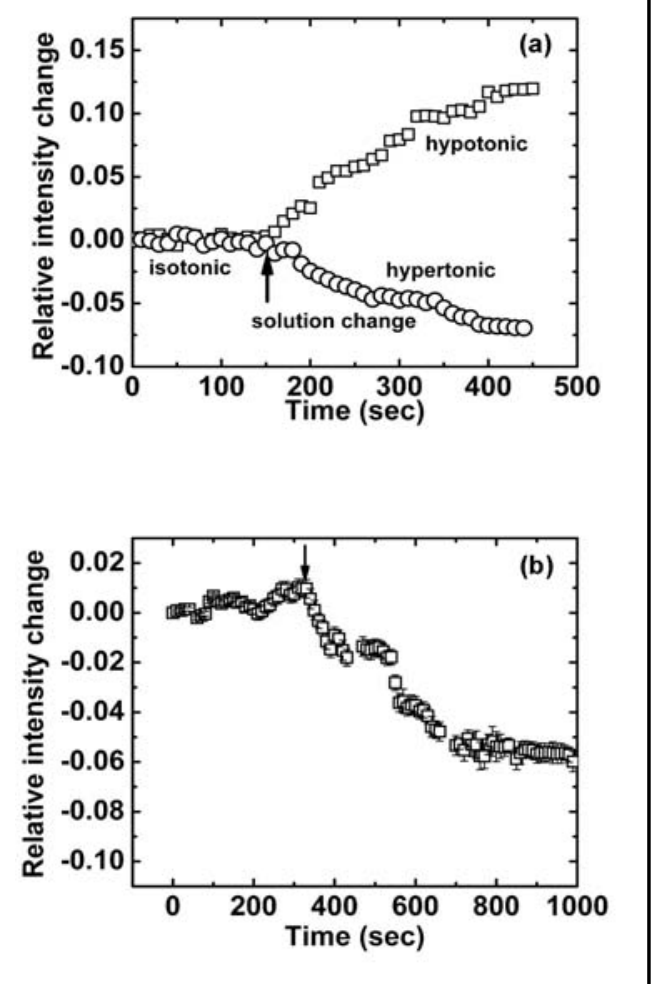

The flow-dependent volume decrease is not an artifact due to the loss of cells from the sensing chamber. We collected optical micrographs every minute during the course of the measurement. Figures 1c-f are micrographs of the cells obtained at 5, 15, 20, and $25 \mathrm{~min}$ in Fig. 1a, showing that MDCK cells were not detached from the surface for shear of $0.2-2.0$ $\mathrm{dyn} / \mathrm{cm}^{2}$. However, shear stress caused large changes in cell morphology at $2.0 \mathrm{dyn} / \mathrm{cm}^{2}$, as indicated by the wide intercellular gaps (this was a widespread phenomenon, two examples were indicated by black arrows in Fig. 1c-f). This data supports the view that the decrease in mean cell volume arose from cell shrinkage, not the loss of cells.

We tested whether a change in flow rate (perfusion pressure) caused the chamber height to increase, which would be interpreted as a reduction in cell volume. There was no significant change in the signal in empty chambers containing fixed and permeabilized MDCK cells when the flow rate was increased (Fig. 1b).

To confirm the effects of shear stress we double checked the data using the fluorescence quenching assay. We first examined whether the fluorescence was sensitive to anisotonic challenges. After stabilized in isotonic solution, the cells were exposed to $168 \mathrm{mOsm}$ solution causing the cells to swell, while a $429 \mathrm{mOsm}$ solution causing the cells to shrink. Figure $2 \mathrm{a}$ shows mean of relative fluorescence intensity from ten different locations, extracted from the time-lapse images. As shown in Fig. 2a, cell swelling increases the fluorescence intensity of calcein due to the reduced quenching and cell shrinkage decreased the intensity. We then applied shear stress to cells loaded with calcein and Fig. $2 \mathrm{~b}$ shows the average intensity from ten different locations in a population of cells. The error bar indicates the standard deviation of ten measurements. When the shear stress increased from 0.7 to $7.0 \mathrm{dyn} / \mathrm{cm}^{2}$, as indicated by the arrow, the fluorescence intensity significantly decreased showing that the shear stress caused cell shrinkage supporting our earlier sensor data.

\section{$\mathrm{Hg}^{2+}$ inhibits the shear-induced volume shrinkage}

To examine whether the volume decrease is a result of water transport via aquaporins (AQPs), we treated cells with $0.1 \mu \mathrm{M} \mathrm{HgCl}_{2}$ and then measured the volume change under shear stress. Fig. 3 shows that $\mathrm{Hg}^{2+}$ significantly inhibited the shear-induced volume decrease. This suggests that the water transport via AQPs is involved with the cell shrinkage 


\begin{tabular}{rl|l} 
Cellular Physiology & Cell Physiol Biochem 2012;30:395-406 & \\
\cline { 2 - 3 } and Biochemistry 10.1159/000339033 & $\begin{array}{l}\text { Dublished online: July 03, 2012 } \\
\text { aww.karger.com/cpb }\end{array}$ \\
\cline { 2 - 3 } & Heo/Sachs/Wang/Hua: Shear-induced Volume Decrease
\end{tabular}

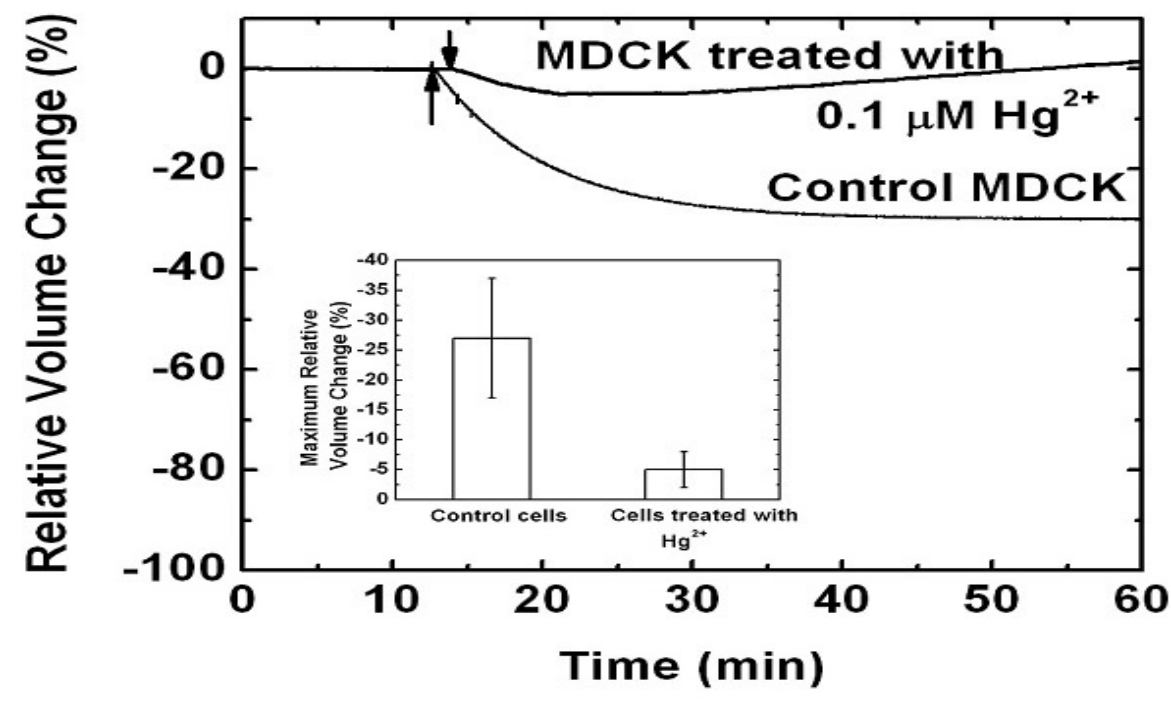

Fig. 3. Volume response of cells to shear stress after mercurial treatment. The MDCK cells were treated with $0.1 \mu \mathrm{M} \mathrm{HgCl}_{2}$ for $1 \mathrm{~min}$ followed by rinsing with isotonic solution. The volume change of the cells under shear stress was measured using the volume sensor. The arrows indicate the change of shear stress from 0.2 to $2.0 \mathrm{dyn} / \mathrm{cm}^{2}$. The graph insert shows the maximum relative volume change of control cells $(\mathrm{n}=3)$ and cells treated with $\mathrm{HgCl}_{2}(\mathrm{n}=4)$. The error bar indicates the standard deviation. The cells treated with $\mathrm{Hg}^{2+}$ showed less cell volume reduction than the control cells suggesting that AQPs were involved.

during shear stress. AQP2 and AQP3 are endogenously expressed in kidney epithelial cells [26] and low level of AQP2, 3 has been observed in wild type MDCK cells [27, 28]. $\mathrm{Hg}^{2+}$ blocks the water permeability of both AQP2 and 3, but lack the blocking effect on AQP4 [23, 29]. While cell shrinkage must be linked with loss of water regardless of mechanism, APQs can affect the kinetics of volume change. The slight increase in cell volume we saw at later times suggests that $\mathrm{Hg}^{2+}$, probably through non-specific effects, may have relaxed the stress in the cytoskeleton by inhibiting myosin, or increased the cell permeability to external salts such as $\mathrm{NaCl}[21,30-32]$.

\section{Slow recovery of flow-dependent shrunken cells}

If water is the only molecule released from the cells by shear stress, cells might be expected to return to their initial volume when the shear stress is removed. However, if the cell anatomy changes, the local stress changes will correlate with osmotic pressure changes [18] and the recovery of cell volume may be delayed or never achieved. Similarly, changes in solute concentration during the change in shape would lead to a delayed recovery. Figure 4a shows a plot of relative cell volume over relatively a long period of time. The cell volume decreased by $\sim 30 \%$ in response to an increase of shear stress from 0.2 to $2 \mathrm{dyn} / \mathrm{cm}^{2}$ as indicated by arrow '1' in Fig. 4(a). When the shear stress was removed (as indicated by the arrow ' 2 '), the cell volume only partially recovered over the duration of the experiment. The removal of shear stress during the cell volume decrease partially recovered the cell volume (Fig. 4(b)).

The shear-induced volume decrease does not involve $\mathrm{Ca}^{2+}$ activated pathways

Using the $\mathrm{Ca}^{2+}$-sensitive dye, Fluo 4, we investigated the role of $\mathrm{Ca}^{2+}$ in the flow-dependent decrease in cell volume. A stepwise change of stress from 0.5 to $5.5 \mathrm{dyn} / \mathrm{cm}^{2}$ caused a transient increase in $\mathrm{Ca}^{2+}$ (Fig. 5a) and a decrease in cell volume (Fig. 5c). We applied $100 \mu \mathrm{M}$ 


\begin{tabular}{|c|c|c|}
\hline \multirow{2}{*}{$\begin{array}{c}\text { Cellular Physiolosy } \\
\text { and Biochemistry }\end{array}$} & \multicolumn{2}{|c|}{ Cell Physiol Biochem 2012;30:395-406 } \\
\hline & $\begin{array}{l}\text { DOI: 10.1159/000339033 } \\
\text { Published online: July 03, } 2012\end{array}$ & $\begin{array}{l}\text { C } 2012 \text { S. Karger AG, Basel } \\
\text { www.karger.com/cpb }\end{array}$ \\
\hline
\end{tabular}

Fig. 4. Volume response to reversible steps in shear stress amplitude showing that the cellular response to shear stress is irreversible on a scale of $30 \mathrm{~min}$. The arrows in (a) and (b) indicate the change of shear stress (1: from 0.2 to $2.0 \mathrm{dyn}$ / $\mathrm{cm}^{2}$ and 2: from 2.0 to $0.2 \mathrm{dyn} / \mathrm{cm}^{2}$ ). Removing high shear stress did not restore the reduced cell volume to the initial value (a).

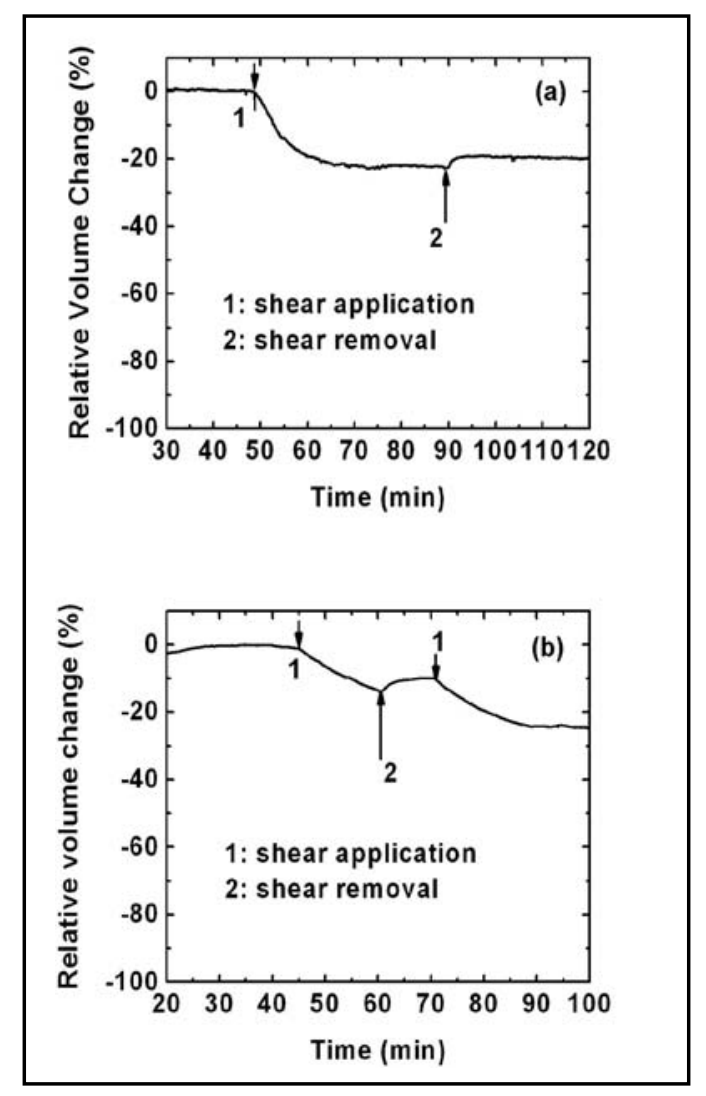

$\mathrm{Gd}^{3+}$, a known inhibitor for non-selective stretch-activated-channels (SACs) [33, 34], to block the $\mathrm{Ca}^{2+}$ entry via SACs. $\mathrm{Gd}^{3+}$ completely blocked the shear-induced $\mathrm{Ca}^{2+}$ entry (Fig. $5 \mathrm{~b}$ ), but it did not affect the shear-induced cell shrinkage (Fig. 5d). These data suggest that the effect of shear stress on cell volume is not associated with $\mathrm{Ca}^{2+}$-activated signal pathways nor with SACs.

The role of ion channels in shear-induced shrinkage of cells

Although renal epithelium has a high intracellular $\mathrm{K}^{+}$, to maintain electroneutrality the efflux of $\mathrm{K}^{+}$must be paralleled by the efflux of $\mathrm{Cl}^{-}$or other anion so transport of $\mathrm{KCl}$ could occur via a pair of commonly available ion channels. Large-conductance $\mathrm{K}^{+}$channels (maxiK) have been detected in the apical membrane of MDCK cells [35, 36]. These channels can be activated by membrane depolarization, increases in intracellular $\mathrm{Ca}^{2+}$ concentration, or membrane stretch [13, 37-39]. To test the role of $\mathrm{K}^{+}$channels we measured the volume response to shear stress in the presence of $75 \mathrm{mM}$ tetraethylammonium (TEA), a known $\mathrm{K}^{+}$channel blocker [40]. As shown in Fig. 6a, substituting $\mathrm{NaCl}$ with TEA $(75 \mathrm{mM})$ did not eliminate the shear-induced shrinkage. This result suggests that $\mathrm{K}^{+}$channels do not play a major role. $\mathrm{A} \mathrm{Cl}^{-}$channel blocker, $100 \mu \mathrm{M}$ DIDS, also had no effect on shrinkage (Fig. 6b). In addition, neither amiloride, an $\mathrm{ENaC}$ inhibitor, nor dimethyl amiloride, a $\mathrm{Na}^{+}-\mathrm{H}^{+}$-exchange (NHE) inhibitor showed any effect (data not shown). Our data using pharmacologic blockers suggests that cell shape (cytoskeletal stress), not solute permeability, is the key player in shear-induced decrease in the cell volume.

\section{Numerical modeling of intracellular stress}

To estimate the influence of flow on intracellular pressure, we built a model of a cell in a flow chamber and calculated the distribution of internal stress using CFD software. The cell was defined as a deformable object with a Young's modulus of $450 \mathrm{~Pa}$ [41]. As shown in Fig. $7 \mathrm{a}$, a flow rate of $5 \mu \mathrm{l} / \mathrm{min}\left(5.5 \mathrm{dyn} / \mathrm{cm}^{2}\right)$ produces a compression in the direction 


\section{Cellular Physiology $\quad$ Cell Physiol Biochem 2012;30:395-406 \\ \begin{tabular}{ll|l} 
and Biochemistry & $\begin{array}{l}\text { DOI: 10.1159/000339033 } \\
\text { Published online: July 03, } 2012\end{array}$ & $\begin{array}{l}\text { C 2012 S. Karger AG, Basel } \\
\text { www.karger.com/cpb }\end{array}$ \\
\cline { 2 - 3 } Heo/Sachs/Wang/Hua: Shear-induced Volume Decrease
\end{tabular}}
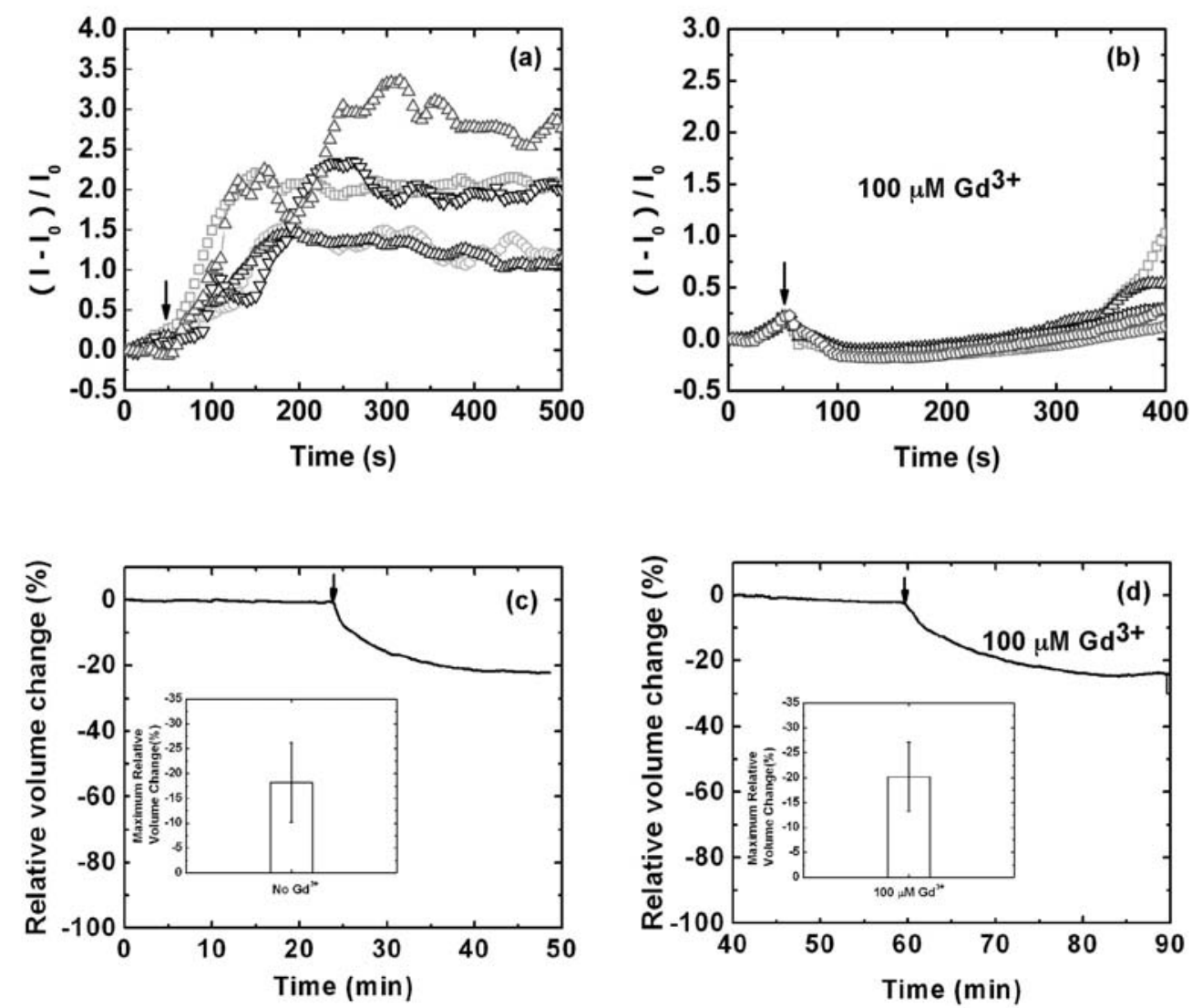

Fig. 5. Effects of shear stress on intracellular $\mathrm{Ca}^{2+}$ and volume showing that the cell volume decrease under the shear stress is $\mathrm{Ca}^{2+}$ independent. (a) $\mathrm{The}^{2} \mathrm{Ca}^{2+}$ increase in response to a stepwise rise of shear stress from 0.5 to $5.5 \mathrm{dyn} / \mathrm{cm}^{2}$. (b) The flow-induced $\mathrm{Ca}^{2+}$ uptake is blocked by $100 \mu \mathrm{M} \mathrm{Gd}^{3+}$. Multiple regions in the chamber are measured and plotted in (a) and (b). (c) Cell volume response to an increase in isotonic shear stress from 0.2 to $2.0 \mathrm{dyn} / \mathrm{cm}^{2}$. (d) Volume response to shear stress in the presence of $100 \mu \mathrm{M}$ of $\mathrm{Gd}^{3+}$ showing $\mathrm{Gd}^{3+}$ does not inhibit the flow induced cell shrinkage. The arrow indicates the change of flow rate. The inserted graphs in (c) and (d) show the average of maximum relative cell volume change obtained from three independent experiments. The error bar indicates the standard deviation.

vertical to the bottom surface (Fig. 7b), indicating an increase in intracellular pressure. An increase in the flow rate enhances the intracellular compression (Fig. 7b). The simulation result suggests that flow induces a decrease in cell volume as a result of compressive stress that raises intracellular hydrostatic pressure.

\section{Discussion}

We report for the first time that cells shrink when subjected to an increase in shear stress. Fluorescence quenching supports the results obtained by the volume sensor. Since cell volume is determined by water content, our results indicate that the shear stress must modulate the water content of the cell. It has been previously reported that AQP2 and 3 are endogenously expressed in kidney epithelium [26] and the water transport via AQP2 and 3 can be irreversibly blocked by $\mathrm{Hg}^{2+}[23,29]$. If the shear-induced cell shrinkage involves the water transport, the blocking of AQPs should inhibit the rate of relaxation of cell volume but cannot affect the endpoints since AQPs are catalysts, not sources of free energy. As shown 


\begin{tabular}{|c|c|c|}
\hline \multirow{2}{*}{$\begin{array}{c}\text { Cellular Physiology } \\
\text { and Biochemistry }\end{array}$} & \multicolumn{2}{|c|}{ Cell Physiol Biochem 2012;30:395-406 } \\
\hline & $\begin{array}{l}\text { DOI: 10.1159/000339033 } \\
\text { Published online: July 03, } 2012\end{array}$ & $\begin{array}{l}\text { C } 2012 \text { S. Karger AG, Basel } \\
\text { www.karger.com/cpb }\end{array}$ \\
\hline
\end{tabular}

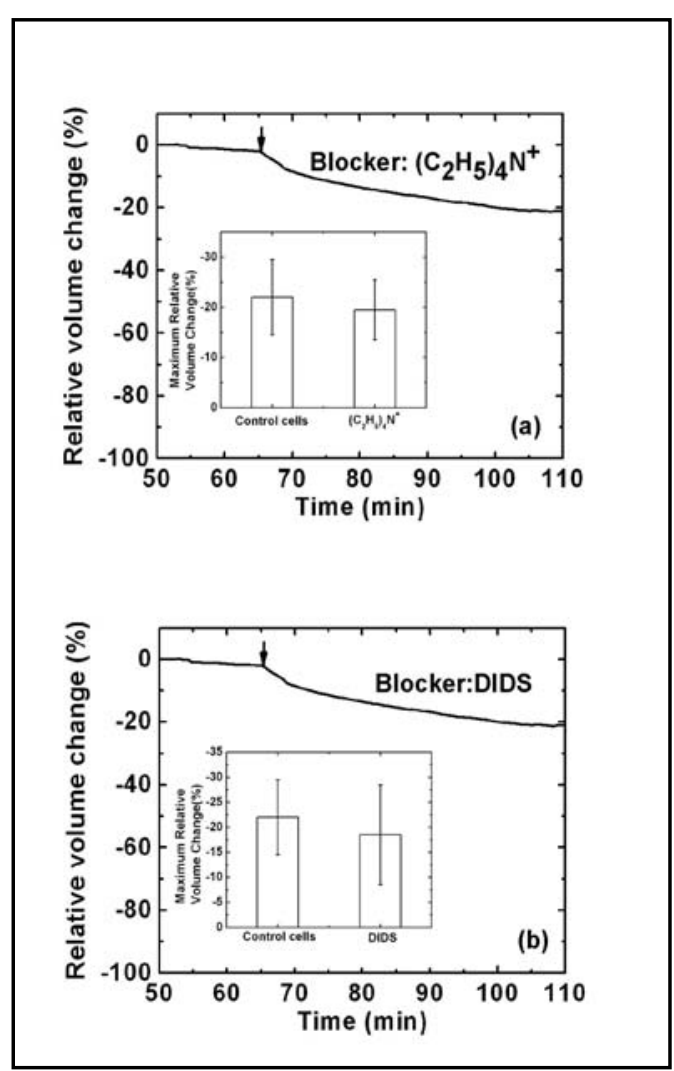

Fig. 6. Cell volume response to flow shear stress in the presence of $75 \mathrm{mM}$ TEA (a) and $100 \mu \mathrm{M}$ DIDS (b) showing that the cell volume decrease in response to shear stress is not likely to be mediated via $\mathrm{K}^{+}$and $\mathrm{Cl}^{-}$channels. The arrow indicates the change of shear stress from 0.2 to $2.0 \mathrm{dyn} / \mathrm{cm}^{2}$. The inserted graphs in (a) and (b) show the average of maximum relative cell volume change obtained from three independent experiments in controls and in the presence of TEA and DIDS, respectively. (a)

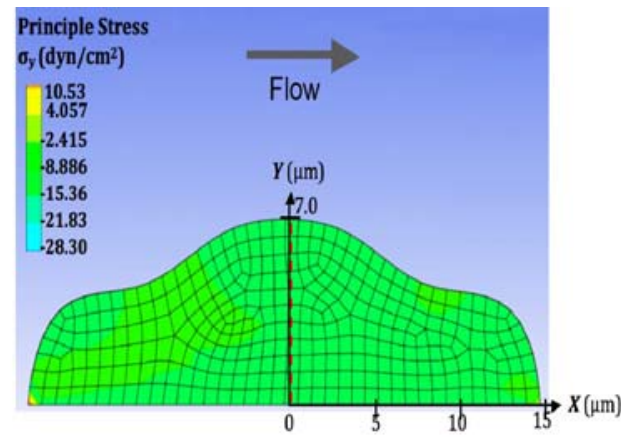

(b)

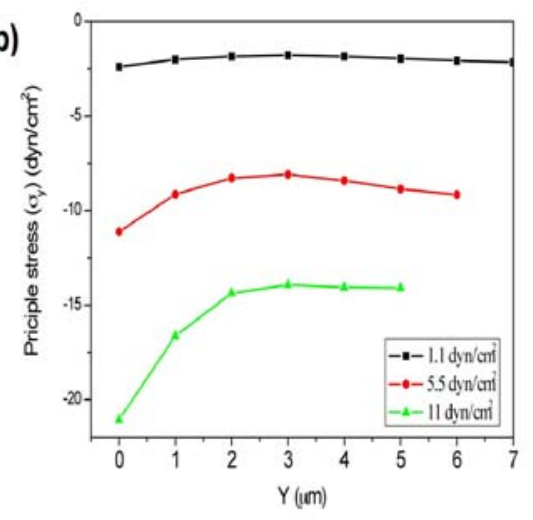

Fig. 7. (a) 2D simulation of the stress distribution in a deformable cell under shear stress (arrow) showing a compression in the transverse direction to flow. The cell modulus was $450 \mathrm{~Pa}$; the flow rate was 5 $\mu \mathrm{l} / \mathrm{min}$ (5.5 dyn $/ \mathrm{cm}^{2}$ ). (b): Stress distribution along the y-direction (from basal to apical surface) at the center plane indicated by red dashed line in (a) at shear stresses of 1.1 (black), 5.5 (red) and 11 (green) dyn/cm2, showing an increase in compression with increased flow.

in Fig. 3, $0.1 \mu \mathrm{M} \mathrm{HgCl}_{2}$ blocked the volume decrease during the shear-stress application suggesting the shear-induced cell shrinkage involves the water transport and AQPs may contribute to the transport of water. The slight increase in volume at later times may have arisen from penetration of $\mathrm{Hg}^{2+}$ since $\mathrm{Hg}^{2+}$ is known to diffuse into cells under stretch causing excessive cell swelling [21].

While the volume decrease could be driven by the loss of solutes through flow-activated pathways, we could show that several common channels were not involved. Flow shear stress affects $\mathrm{Ca}^{2+}$-activated $\mathrm{K}^{+}$channels known to be blocked by TEA or quinidine [36] and possibly SACs $[16,37,42,43]$. The flow-induced volume decrease might result from the solute movement but there must be anionic and cationic channels active so that the net charge of transferred solutes is neutral $[18,43]$. Previously, large-conductance $\mathrm{K}^{+}$channels (maxi-K) have been identified in MDCK cells and known to be blocked by TEA or quinidine [36]. Our data shows that flow-induced volume decrease could not be blocked by $\mathrm{K}^{+}$channel blocker (TEA) nor $\mathrm{Cl}^{-}$channel blocker (DIDS) (Fig. 6), suggesting that maxi- $\mathrm{K}^{+}$channel was not the major source for the volume decrease. $\mathrm{Na}^{+}-\mathrm{H}^{+}$exchanger blockade did not prevent the cell shrinkage by shear stress (data not shown), eliminating the involvement of exchanger in 


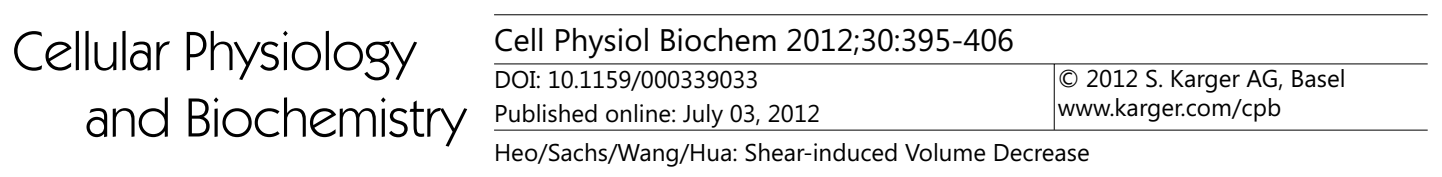

shear-induced release of solutes.

SACs exhibit mechanosensitivity to both osmotic swelling and fluid shear stress [16, $17]$ and may contribute to RVD in some cell types [44,45]. These channels are endogenously expressed in all cell types including renal epithelial cells, notably in the distal nephron and collecting ducts $[17,46,47]$. Since $100 \mu \mathrm{M} \mathrm{Gd}^{3+}$ was not able to inhibit the volume decrease by shear flow, while it did inhibit the regulatory volume decrease following osmotic stimuli [48], it is likely that MDCK cells do not use the same channels for mediating flow-induced volume change. Based on the lack of effect of ion channel blockers on shearinduced shrinkage (Fig. 6a,b) and the slow recovery of cell volume (Fig. 4a,b) we suspect that the shear stress effects on cell volume arise from flow-induced changes in cell shape or equivalently changes in cytoskeletal stress. This change in cell shape would significantly raise intracellular hydrostatic pressure resulting in an efflux of water. Our sensor measures changes in the volume of a population cells as defined by the volume enclosed by the plasma membrane. Modeling the cell as a deformable object, finite element calculations show that the internal compressive stresses rise as the cell is deformed. This indicates an increase in pressure within the cell. Given that the water flux across the membrane is driven by both osmotic and hydrostatic pressure, we suggest that the initial water efflux in response to the flow can be driven by internal pressure in parallel with solute transport. Changes in cell shape involve both passive and active changes in cytoskeletal structure. Because the changes in cross-linking take time to relax [49], the elimination of flow shear stress will not restore the shrunken cells to their initial volume in a short period of time as shown in Fig. 4a and 4b. Alternatively, but not exclusively, there may be some loss of intracellular solutes that are not contained in the perfusion solution so the cells could never return to their starting volume. In summary, flow shear causes cells, MDCKs in particular, to shrink and the shrunken cells do not recover over a period of $30 \mathrm{~min}$ after the removal of the flow. The volume change is the result of water transport across the membrane possibly driven by hydrostatic pressure.

\section{Acknowledgements}

This work is supported by grants from the National Institute of Diabetes and Digestive and Kidney Diseases Grant DK77302, and NIHLBI to (F.S).

\section{References}

1 Taniguchi J, Imai M: Flow-dependent activation of maxi $\mathrm{K}^{+}$channels in apical membrane of rabbit connecting tubule. J Membr Biol 1998;164:35-45.

2 Satlin LM, Sheng S, Woda CB, Kleyman TR: Epithelial $\mathrm{Na}^{+}$channels are regulated by flow. Am J Physiol Renal Physiol 2001;280:F1010-1018.

3 Duan Y, Gotoh N, Yan Q Du Z, Weinstein AM, Wang T, Weinbaum S: Shear-induced reorganization of renal proximal tubule cell actin cytoskeleton and apical junctional complexes. Proc Natl Acad Sci USA 2008;105:16483-16488.

4 Essig M, Terzi F, Burtin M, Friedlander G: Mechanical strains induced by tubular flow affect the phenotype of proximal tubular cells. Am J Physiol Renal Physiol 2001;281:F751-F762.

5 Wang J, Heo J, Hua SZ: Spatially resolved shear distribution in microfluidic chip for studying force transduction mechanisms in cells. Lab Chip 2010;10:235-239.

6 Kaysen JH, Campbell WC, Majewski RR, Goda FO, Navar GL, Lewis FC, Goodwin TJ, Hammond TG: Select de novo gene and protein expression during renal epithelial cell culture in rotating wall vessels is shear stress dependent. J Membr Biol 1999;168:77-89.

7 Carattino MD, Sheng S, Kleyman TR: Epithelial $\mathrm{Na}^{+}$channels are activated by laminar shear stress. J Biol Chem 2004;279:4120-4126.

8 Jensen ME, Odgaard E, Christensen MH, Praetorius HA, Leipziger J: Flow-induced $\left[\mathrm{Ca}^{2+}\right]_{\mathrm{i}}$ increase depends on nucleotide release and subsequent purinergic signaling in the intact nephron. J Am Soc Nephrol 2007;18:2062-2070. 
9 Liu W, Xu S, Woda C, Kim P, Weinbaum S, Satlin LM: Effect of flow and stretch on the $\left[\mathrm{Ca}^{2+}\right]_{\mathrm{i}}$ response of principal and intercalated cells in cortical collecting duct. Am J Physiol 2003;285:F998-F1012.

10 Mo M, Eskin SG, Schilling WP: Flow-induced changes in $\mathrm{Ca}^{2+}$ signaling of vascular endothelial cells: Effect of shear stress and atp. American Journal of Physiology Heart Circulation Physiology 1991;260:H1698H1707.

11 Schwartz G, Callewaert G, Droogmans G, Nilius B: Shear stress induced calcium transients in endothelial cells from human umbelical cord veins. J Physiol (Camb) 1992;458:527-538.

12 Quinlan MR, Docherty NG, Watson RW, Fitzpatrick JM: Exploring mechanisms involved in renal tubular sensing of mechanical stretch following ureteric obstruction. Am J Physiol Renal Physiol 2008;295:F1-F11.

13 Woda CB, Bragin A, Kleyman TR, Satlin LM: Flow-dependent $\mathrm{K}^{+}$secretion in the cortical collecting duct is mediated by a maxi-k channel. Am J Physiol Renal Physiol 2001;49:F786-793.

14 Liu W, Morimoto T, Woda C, Kleyman TR, Satlin LM: $\mathrm{Ca}^{2+}$ dependence of flow-stimulated k secretion in the mammalian cortical collecting duct. Am J Physiol Renal Physiol 2007;293:F227-235.

15 Markin VS, Sachs F: Thermodynamics of mechanosensitivity. Physical Biology 2004;1:110-124.

16 Wu L, Gao X, Brown RC, Heller S, O'Neil RG: Dual role of the trpv4 channel as a sensor of flow and osmolality in renal epithelial cells. Am J Physiol Renal Physiol 2007;293:F1699-1713.

17 O'Neil RG, Heller S: The mechanosensitive nature of trpv channels. Pflugers Arch 2005;451:193-203.

18 Spagnoli C, Beyder A, Besch S, Sachs F: Atomic force microscopy analysis of cell volume regulation. Phys Rev E Stat Nonlin Soft Matter Phys 2008;78:031916.

19 Johnson CP, Tanbg HY, Carag C, Speicher D, Discher DE: Forced unfolding of proteins within cells. Science 2007

20 Ateya DA, Sachs F, Gottlieb PA, Besch S, Hua SZ: Volume cytometry: Microfluidic sensor for high-throughput screening in real time. Anal Chem 2005;77:1290-1294.

21 Heo J, Meng F, Sachs F, Hua SZ: Dynamic effects of $\mathrm{Hg}^{2+}$-induced changes in cell volume. Cell Biochem Biophys 2008;51:21-32.

22 Fricke H: A mathematical treatment of the electrical conductivity of colloids and cell suspensions. J Gen Physiol 1924;6:375-384.

23 Heo J, Meng F, Hua SZ: Contribution of aquaporins to cellular water transport observed by a microfluidic cell volume sensor. Anal Chem 2008;80:6974-6980.

24 Hamann S, Kiilgaard JF, Litman T, Alvarez-Leefmans FJ, Winther BR, Zeuthen T: Measurement of cell volume changes by fluorescence self-quenching. Journal of Fluorescence 2002;12:139-145.

25 Fox RW, McDonald AT: Introduction to fluid mechanics, ed 4th. New York, J. Wiley, 1992.

26 Baum MA, Ruddy MK, Hosselet CA, Harris HW: The perinatal expression of aquaporin-2 and aquaporin-3 in developing kidney. Pediatr Res 1998;43:783-790.

27 Yui N, Lu HJ, Bouley R, Brown D: Aqp2 is necessary for vasopressin- and forskolin-mediated filamentous actin depolymerization in renal epithelial cells. Biology Open 2012;1:101-108.

28 Matsuzaki T, Suzuki T, Takata K: Hypertonicity-induced expression of aquaporin 3 in mdck cells. American Journal of Physiology - Cell Physiology 2001;281:C55-C63.

29 Meinild AK, Klaerke DA, Zeuthen T: Bidirectional water fluxes and specificity for small hydrophilic molecules in aquaporins 0-5. J Biol Chem 1998;273:32446-32451.

30 Vassallo DV, Moreira CM, Oliveira EM, Bertollo DM, Veloso TC: Effects of mercury on the isolated heart muscle are prevented by dtt and cysteine. Toxicol Appl Pharmacol 1999;156:113-118.

31 Ballatori N, Boyer JL: Disruption of cell volume regulation by mercuric chloride is mediated by an increase in sodium permeability and inhibition of an osmolyte channel in skate hepatocytes. Toxicol Appl Pharmacol 1996;140:404-410.

32 Rothstein A, Mack E: Actions of mercurials on cell volume regulation of dissociated mdck cells. Am J Physiol 1991;260:C113-121.

33 Yang XC, Sachs F: Block of stretch-activated ion channels in xenopus oocytes by gadolinium and calcium ions. Science 1989;243:1068-1071.

34 Caldwell RA, Clemo HF, Baumgarten CM: Using gadolinium to identify stretch-activated channels: Technical considerations. Am J Physiol 1998;275:C619-621.

35 Rothstein A, Mack E: Volume-activated calcium uptake: Its role in cell volume regulation of madin-darby canine kidney cells. Am J Physiol 1992;262:C339-347.

36 Bolivar JJ, Cereijido M: Voltage and $\mathrm{Ca}^{2+}$-activated $\mathrm{K}^{+}$channel in cultured epithelial cells (mdck). J Membr Biol 1987;97:43-51.

37 Irnaten M, Barry RC, Quill B, Clark AF, Harvey BJP, O'Brien CJ: Activation of stretch-activated channels and maxi- $\mathrm{K}^{+}$channels by membrane stress of human lamina cribrosa cells. Investigative Ophthalmology \& Visual Science 2009;50:194-202.

38 Pacha J, Frindt G, Sackin H, Palmer LG: Apical maxi K channels in intercalated cells of cct. Am J Physiol 1991;261:F696-705.

39 Hirsch J, Leipziger J, Frobe U, Schlatter E: Regulation and possible physiological role of the $\mathrm{Ca}^{2+}$-dependent $\mathrm{K}^{+}$channel of cortical collecting ducts of the rat. Pflugers Arch 1993;422:492-498.

40 Geyti CS, Odgaard E, Overgaard MT, Jensen JME, Praetorius HA: Slow spontaneous [ $\mathrm{Ca}^{2+}$ ] oscillations reflect nucleotide release from renal epithelia. Pflueg Arch Eur J Physiol 2008;455:1105-1117. 


\section{Cellular Physiology Cell Physiol Biochem 2012;30:395-406 and Biochemistry \begin{tabular}{l|l}
\hline DOI: $10.1159 / 000339033$ & C 2012 S. Karger AG, Basel
\end{tabular} www.karger.com/cpb}

41 Alcaraz J, Buscemi L, Grabulosa M, Trepat X, Fabry B, Farre R, Navajas D: Microrheology of human lung epithelial cells measured by atomic force microscopy. Biophys J 2003;84:2071-2079.

42 Filipovic D, Sackin H: A calcium-permeable stretch-activated cation channel in renal proximal tubule. Am J Physiol 1991;260:F119-129.

43 Holtzclaw JD, Liu L, Grimm PR, Sansom SC: Shear stress-induced volume decrease in c11-mdck cells by bk$\alpha / \beta 4$. American Journal of Physiology - Renal Physiology 2010;299:F507-F516.

44 Becker D, Blase C, Bereiter-Hahn J, Jendrach M: Trpv4 exhibits a functional role in cell-volume regulation. J Cell Sci 2005;118:2435-2440.

45 Numata T, Shimizu T, Okada Y: Trpm7 is a stretch- and swelling-activated cation channel involved in volume regulation in human epithelial cells. Am J Physiol 2007;292:C460-467.

46 Tian W, Salanova M, Xu H, Lindsley JN, Oyama TT, Anderson S, Bachmann S, Cohen DM: Renal expression of osmotically responsive cation channel trpv4 is restricted to water-impermeant nephron segments. Am J Physiol Renal Physiol 2004;287:F17-24.

47 Delany NS, Hurle M, Facer P, Alnadaf T, Plumpton C, Kinghorn I, See CG, Costigan M, Anand P, Woolf CJ, Crowther D, Sanseau P, Tate SN: Identification and characterization of a novel human vanilloid receptorlike protein, vrl-2. Physiol Genomics 2001;4:165-174.

48 Hua SZ, Gottlieb PA, Heo J, Sachs F: A mechanosensitive ion channel regulating cell volume. Am J Physiol 2010;298:C1424-1430.

49 Deng LH, Trepat X, Butler JP, Millet E, Morgan KG, Weitz DA, Fredberg JJ: Fast and slow dynamics of the cytoskeleton. Nature Materials 2006;5:636-640. 